369. Xenon CTにおける動脈血中xenon濃度測定法の検討 一Xenon濃度計法と終末呼気チャンバー法の比較—

Examination of methods for measurement of arterial xenon concentration in Xenon-CT

(株)東芝那須工場 ○南部恭二郎 - 東京医科歯科大学 脳神経外科 鈴木龍太 (Kyojiro Nambu) 東芝メディカル(株) 武藤安弘・安西メディカル(株) 土屋秀二 安西総業(株) 小林由和・東京女子医科大学神経放射線科 小林直紀

(Yoshikazu Kobayashi)

【目的】局所脳血流量 $\mathrm{rCBF}$ を測定するXenon CT検査においては、CTスキャンの他に、動脈血中キセ ノン濃度曲線 $\mathrm{Ca}(\mathrm{t})$ の測定が必要である。Ca(t) は普通、終末呼気中キセノン濃度を測定して間接的に 求める。普及している終末呼気中キセノン濃度湘定法として「キセノン濃度計法(Xeモニタ法)」と「終 末呼気チャンバースキャン法(ETC法)」があるが、両者を直接に対此した検討は従来なされていない。 そこで、特にrCBF解析結果にどの程度の違いが現れるかに注目して両者の相互の相関を検討した。

【方法】（1）キセノン吸入装置 Xetron-III を改造し、キセノン濃度計(Xeモニタ)と䅂末呼気チャンバ 一(ETC)を両方同時に使用できるようにした。

(2) Xeモニタはキセノン濃度を体積\%濃度単位で測定するので、これをCT值(HU単位)に換算する必 要がある。CT装置 Xforce $120 \mathrm{kV} \mathrm{X}$ 線を使用したXenon CT検査に打ける換算係数を実測するために、 $210 \mathrm{~mm} \phi$ 水ファントムの脇に $25 \mathrm{~mm}$ ゆ筒を取付け、種々の濃度のキセノン - 酸素混合ガスを灌流させ つつCTスキャンし、ガスのCT值を測定した。同時にガスの\%濃度をXeモニタで測定した。両者の測定 值から回帰直線を求め、換算係数 $=1.65[\mathrm{HU} / \%]$ を得た。

（3）患者・ボランティア14例にXenon CT検査を施行し、Xeモニタ法とETC法で Ca(t)を測定した。検 査は30〜33\%Xe+Oxygen 4 5分間吸入、CT撮影は吸入開始直前から吸入終了後 2分まで、30〜60秒毎 とした。

（4） $\mathrm{Ca}(\mathrm{t})$ の測定結果を定量比較するにあたり、rCBF解析結果の相関を反映すると思われる相関評価 関数 $\mathrm{q}(\mathrm{t})$ を新しく考案・適用した。また、それぞれの測定法で得た $\mathrm{Ca}(\mathrm{t})$ を用いて $\mathrm{rCBF} ッ$ た゚、, $\lambda$ マッ プを作成し、対比した。

【結果】両者の方法で得た $\mathrm{Ca}(\mathrm{t})$ は良く近似していた。両者の方法による相関評価関数 $\mathrm{q}(\mathrm{t})$ の相関係数

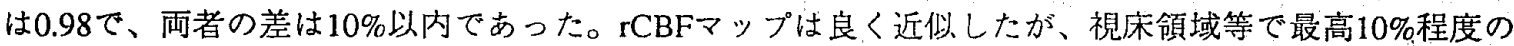
差が認められた。入マップは互いに良く近似した。

【結論】（1）キセノン濃度計法と終末呼気チャンバー法による動脈血中キセノン濃度測定值は互い

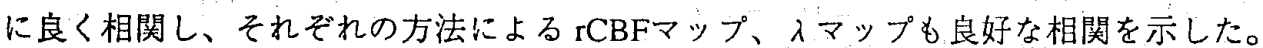

（2）相関評価関数 $\mathrm{q}(\mathrm{t})$ は両者の定量的比較に有用であった。

（3）キセノン濃度計法では、\%濃度からCT值への換算係数を実測する必要がある。

\section{相関評価用関数 $\mathrm{q}(\mathrm{t})=\int_{0}^{\mathrm{t}} \mathrm{Cd}(\mathrm{t}) e^{-0.5 \mathrm{t}} \mathrm{dt}$}

実測例 : 正常ボランティア 5分吸入

$\mathrm{Ca}(\mathrm{t})[$ H.U.],

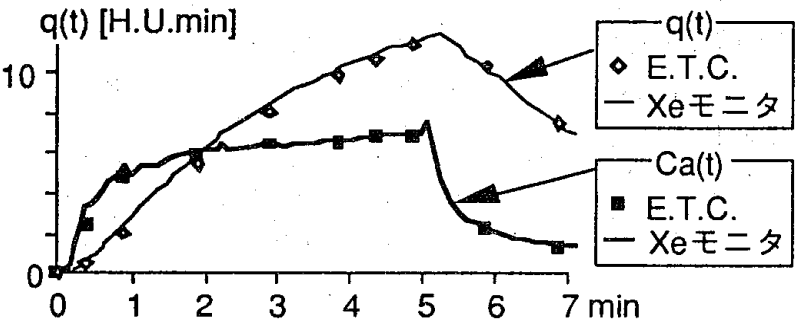

$\mathrm{q}(\mathrm{t})$ の相関

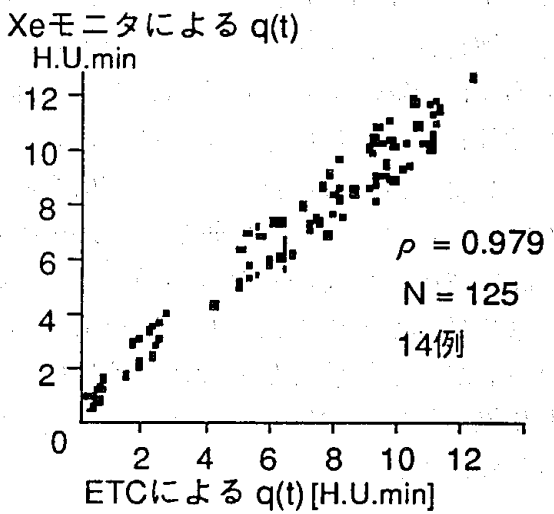

